\title{
CHEMICAL AND STRUCTURAL CONSTRAINTS ON THE PAIOL GOLD DEPOSIT, ALMAS GREENSTONE BELT, BRAZIL
}

\section{MÁRCIO ANSELMO DUARTE FERRARI ${ }^{1}$ AND ASIT CHOUDHURI ${ }^{1}$}

\begin{abstract}
This paper presents new structural, chemical and fluid inclusion data for the volcanic sequences of the Almas greenstone belt (AGB), Tocantins State. The volcanic rocks were metamorphosed up to amphibolite facies, during a regional tectono-metamorphic event (D ) and then retrogressed to greenschist facies assemblages along with later hydrothermal alteration, associated to sinistral strike-slip shear zones (D ). Chemical composition of the rocks of the volcanic sequence show that it has continental affinity, probably related to a continental rift environment. In the Paiol gold mine of AGB the mineralized zones are associated with metabasaltic rocks. A detailed structural study shows that the gold mineralization can be related to the intersection of penetrative $S_{n+1}$ mylonitic foliation with extensional faults $\left(S_{n+2}\right)$, filling open spaces in transtension zones through which hydrothermal fluids passed resulting in ore shoot zones.
\end{abstract}

INTRODUCTION Greenstone belts worldwide are sites of important ore deposits, and Brazil in no exception in this respect. In general, gold mineralization in Brazil is found associated with volcanic sequences of Archaean and Paleoproterozoic greenstone belts. Among these, the AGB (Costa 1984), located at the southern part of the Tocantins State, is the focus of this study (Fig.1). The AGB consists of a lower, thick sequence of metavolcanic rocks called Córrego Paiol Formation, followed by a relatively thin metasedimentary unit at the top, the Morro do Carneiro Formation. Late kinematic granitic intrusions cut the supracrustal sequence.

GEOLOGY AND REGIONAL STRUCTURE The metavolcanic rocks of the Córrego Paiol Formation occur in a north-south belt of the AGB. These rocks were metamorphosed in amphibolite facies during a regional tecto-metamorphic event $\left(\mathrm{D}_{\mathrm{n}}\right)$, and then retrogressively altered to greenschist facies assemblages followed by a later, hydrothermal alteration phase linked to late sinistral strike-slip shear zones $\left(\mathrm{D}_{\mathrm{n}+1}\right)$ event.
The AGB hosts important gold mineralizations, such as the Paiol deposit. In this deposit, mineralized zones are associated with metabasalts and also with granitic intrusions (Fig.1). The earlier are controlled by $\mathrm{D}_{\mathrm{l}}$ shear zones and the later are related to structurally shallower, radial, brittle shear zones ( $\mathrm{D}_{\mathrm{n}+2}$ event).

Costa et al. (1976), recognized that the AGB has an Y shaped map geometry, curving around the granite-gneiss complex. Regionally, two different structural domains were recognized (Cruz 1993): early structures related to the $\mathrm{D}_{\mathrm{n}}$ event, and late strike-slip structures related to $\mathrm{D}_{\mathrm{n}+1}$ event.

TECTONIC AND STRUCTURAL SETTING OF PAIOL GOLD MINE The Paiol Gold Mine is situated in volcanic strata that are nearly vertical with $\mathrm{N} 20^{\circ} \mathrm{E} / 70^{\circ} \mathrm{NW}$ orientation (Fig.2). Gold mineralization is lode-type quartz sulphide veins linked to strongly sheared metavolcanic rocks.

Ductile Event ( $\left.\mathbf{D}_{\mathbf{n}}\right) \quad$ At the mine and neighboring areas, contacts contouring granite-gneiss are complex, and the $\mathrm{D}_{\mathrm{n}}$ structures are rarely

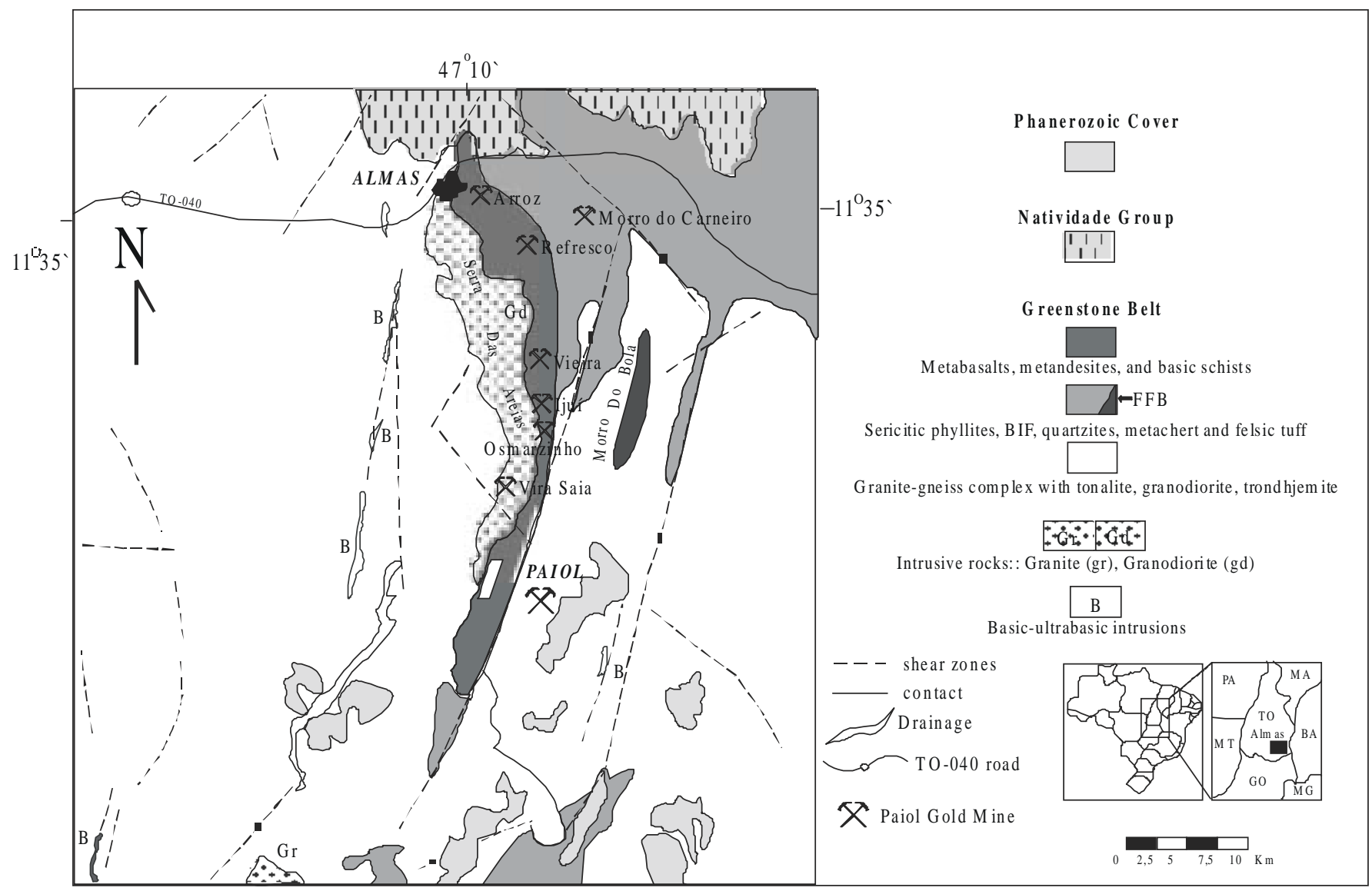

Figure 1-Geological map of SW Tocantins State, (modified from Padilha 1994).

1 Departamento de Metalogênese e Geoquímica, Instituto de Geociências, UNICAMP, CP 6152, CEP 13083-970, Cidade Universitária Zefferino Vaz, Barão Geraldo, Campinas, São Paulo, Brazil; E-mail: ferreri@ige.unicamp.br, asit@ige.unicamp.br. 
observed. However, in the field, early $\mathrm{D}_{\mathrm{n}}$ structures such as schistosity $\left(\mathrm{S}_{\mathrm{n}}\right)$, isoclinal folds, and nearly horizontal $\mathrm{N}$ or $\mathrm{SW}$ dipping mineral lineation $\left(\mathrm{L}_{\mathrm{n}}\right)$ were recognized. $\mathrm{S}$ is strike-slip sub-vertical, mainly NS or NE-SW trending, and tends to be parallel to the greenstone belt contact. Anastomosed schistosity patterns ( $\mathrm{D}$ domain) were observed at the mine site in quartz-sericite-carbonate-schist in which small folds in the quartz-carbonate layer can be recognized. Along the $D_{n+1}$ shear zones, these folds were transposed to " $Z$ " symmetric to disharmonic isoclinal tight folds with ruptured flanks. Dn metamorphism reached the amphibolite facies, represented by hornblende + andesine, in metagabbros which at times still have original subophitic textures.

Ductile-Brittle Event ( $\left.\mathbf{D}_{n+1}\right)$ The $\mathrm{D}_{\mathrm{n}+1}$ structures recognized in the greenstone belt are related to transcurrent shear zones, with dextral movement, dipping steeply eastward or westward, and strike N0-10 $\mathrm{E}$, with sub-horizontal NNE and SSW dipping stretching lineation $\left(\mathrm{L}_{\mathrm{n}+\mathrm{C}}\right)$.

In this domain, mylonitic schistosity $\left(\mathrm{S}_{\mathrm{m}}=\mathrm{S}\right), \mathrm{S}-\mathrm{C}$ and $\mathrm{C}^{\mathrm{C}}$; structures occur, as well as stretching lineation $\left(\mathrm{L}_{\mathrm{m}+1}^{\mathrm{n}}\right)$ and $\mathrm{S}, \mathrm{SL}$ tectonites. $S$ is related to a dextral transcurrent shear zone bundle with N-S, NE-SW, dip $70^{\circ}$ to NW and, subordinately, to SE or NE. Stretching lineation $\left(\mathrm{L}_{\mathrm{m}+1}\right)$ represented by rods and flattened quartz, axis of elliptic platy minerals, range from nearly horizontal 25 to $30^{\circ}$ SW or S.

The $\mathrm{D}_{\text {it }}$ shear zones have deformed the whole sequence of basaltic rocks, which then served as conduits for the rise of hydrothermal fluids. The initial greenschist facies assemblage (actinolite, chlorite, albite and epidote) was later replaced by hydrothermal process coupled with $\mathrm{CO}_{2}$ metasomatism producing carbonate, biotite and chlorite.

Brittle Event $\left(\mathbf{D}_{\boldsymbol{n + 2}}\right) \quad$ Related to this final deformation there are three main fracture families: 1) trend $\mathrm{F} 1$, NS with dipping $80^{\circ}$ to west; 2) trend F2, NW-SE dipping $70^{\circ}$ to east, and 3) F3, nearly horizontal with dips of $35^{\circ}$ to SE or NW. NE-SW fault planes dipping $80^{\circ}$ to SE, and contain NW-SE fault grooves, dipping $55^{\circ}$ to NE. The fracture families are compatible with partition, distension and extension planes or Riedel's T, shear fractures, R synthetics and secondary synthetics $\mathrm{P}$.

GOLD MINERALIZATION IN THE TECTONICSTRUCTURAL CONTEXT Gold mineralization is associated with basaltic metavolcanic rocks that were strongly sheared and hydrothermalized during $\mathrm{D}_{\mathrm{n}+1}$ event. This event produced silicification, sulphidation and potassium alteration halos around the gold mineralization (Silva et al. 1990). Structural data are in agreement with drill logs that show that the ore plunge is $70^{\circ} / \mathrm{N} 70 \mathrm{~W}$. Therefore, the mineralization is not controlled by the stretching lineation direction, $\left(25^{\circ}\right.$ to $\mathrm{SW}$ or $\left.\mathrm{S}\right)$ instead, the ore plunge is perpendicular to the stretching lineation, as observed in the mine. The control of gold mineralization of the Paiol Gold Mine, is related to the strike-slip sinistral shear zones ( $\mathrm{D}_{\text {it }}$ event), and remobilization during later radial brittle shear zones ( $D_{n+2}$ event). Our preliminary model indicates that the ore shoots are placed where the mylonitic foliation $\left(S_{n+1}\right)$ is cut by extensional brittle faults of the $\mathrm{D}_{\mathrm{n}+2}$ event (Ferrari and Choudhuri 1999a). These faults possibly served as conduits for the rise and transport of gold-rich hydrothermal fluids.

CHEMICAL DATA AND FLUID INCLUSIONS Samples of metavolcanic rocks from drill cores (FD, FPA hole) have been analyzed for major, minor and trace elements by atomic absorption and X-ray fluorescence, at the Geochemical Laboratory of Institute of Geoscience - Unicamp

The least altered metavolcanic rocks from drill cores fall in the high-Fe tholeiitic basalt field in a Jensen (1976) diagram, while a few plot as andesites and dacites (Fig.3).

Major and Trace Elements Geochemical behavior of major end trace elements during the metamorphism and hydrothermal alteration led to a strong positive correlation between $\mathrm{Fe}$ and $\mathrm{Ca}$, whereas $\mathrm{Al}$ and alkalis are mobilized to various degrees. Apparently, a correlation of major elements with $\mathrm{MgO}$ suggests an increase in $\mathrm{Mg}$, $\mathrm{Fe}, \mathrm{Ca}$ and loss of $\mathrm{Si}$ and $\mathrm{Al}$.

Relict igneous textures (sub-ophitic) are rare in metabasalts, as textures in almost all rocks were obliterated during the metamorphism and accompanying deformation. The metavolcanic rocks were metamorphosed in amphibolite facies, with replacement of clinopyroxene by hornblende, formation of less calcic plagioclase (andesine), $\mathrm{Ca}$ and $\mathrm{Fe}$ being incorporated in the amphibole.

Increase in $\mathrm{Na}$ and $\mathrm{K}$ is due to transformation of andesine to oligoclase, the remaining $\mathrm{Ca}$ being incorporated in epidote and carbonate. $\mathrm{K}$ is incorporated in biotite and muscovite during retrogressive alteration to greenschist facies assemblages $\left(D_{n+1}\right.$ event).

$\mathrm{Zr}$ and $\mathrm{Ti}$ were chosen, for basalt discrimination as they are immobile under most conditions of hydrothermal activity and up to medium metamorphic grades; both $\mathrm{Ti}$ and $\mathrm{Zr}$ are incompatible elements during partial melting of mantle peridotite which gives rise to basaltic magmas (Rollinson 1999). Basaltic rocks of the Paiol Mine were classified as high-Ti and $\mathrm{Zr}$. When we plot $\mathrm{Y}$ versus $\mathrm{Zr}$ the results show a good correlation and the trend suggests that both elements were immobile since the eruption of the basalts.

The analyzed samples show enrichment of LREE with respect to $\operatorname{HREE}\left(\mathrm{La} / \mathrm{Yb}_{\mathrm{n}}=7,3\right)$, and the geochemical affinities are typical of high-Ti basalts and andesite-basalts (Fig. 4).

Geotectonic Environment The diagram of Pearce et al. (1977) together with $\mathrm{MgO}, \mathrm{FeO}$ and $\mathrm{Al}_{2} \mathrm{O}_{3}$ oxides suggest that the rocks investigated have continental affinities (Fig.5; Ferrari and Choudhuri $1999 b$ ). The $\mathrm{Zr} / \mathrm{Y}$ ratio against $\mathrm{Zr}$ (Pearce and Norry 1979) was used to identify different types of geotectonic environment, and strongly suggest that the volcanic rocks of the AGB formed in a within-plate setting (Fig.6).

Fluid Inclusion studies in the AGB At the Paiol Gold Mine, fluid inclusions from lode-vein quartz in mineralized zones are abundant and can be divided into primary, pseudosecondary and secondary, according to the criteria of Roedder (1984). In keeping with phase relations at room temperature, the investigated fluid inclusions were classified as: type I - two-phase inclusions with a predominant aqueous liquid phase $(\mathrm{L}>\mathrm{V})$ and a subordinate vapor phase; type II three phase inclusions with aqueous liquid, vapor and one or more daughter minerals; type III - one-phase inclusions with aqueous liquid. Most of the primary-like inclusions in quartz occur isolated or in isolated groups, varying from 10 to $50 \mu \mathrm{m}$ in size. The morphology includes types varying from negative crystals, to tabular and irregular to sub-spherical shapes with serrated borders. The pseudo-secondary types have sub-spherical shape $(<15 \mu \mathrm{m}$ in diameter) and occur in oriented arrays along short, healed microfractures. The secondary inclusions are small (1-5 $\mu \mathrm{m}$ in diameter), with very flat and irregular morphologies, that make the microthermometry studies of this family difficult. The vapor phase defined by relation between $\mathrm{V}_{\text {lig }} / \mathrm{V}_{\text {whole }}$, frequently fills nearly 0,9 to 0,7 of the bulk volume of fluid inclusion cavities, suggesting homogeneous fluid on the trapping moment. But, in some cases there are also heterogeneous fluid inclusions with the vapor phase, filling nearly 0,2 to 0,4 of the volume of fluid inclusion cavities, identified as boiling. Necking-down, leakage and decrepitation were found for some fluid inclusions, and are thought to have originally formed by processes of brittle deformation after trapping in cavities and growing thermal gradient that eventually caused partial or total loss of fluids.

Microthermometry of Fluid Inclusions The fluid inclusion measurements were carried out by heating-freezing stage at the Fluid Inclusion Laboratory of IG-Unicamp. The stage was calibrated using synthetic inclusions containing pure water, manufactured by Syn Flinc.

In the Type I fluid inclusions, the temperatures of eutectic point (Te) are in the ranges $-41^{\circ} \mathrm{C}$ to $-34^{\circ} \mathrm{C}$, suggesting fluids belonging to the $\mathrm{H}_{2} \mathrm{O}-\mathrm{MgO}-\mathrm{NaCl}$ or $\mathrm{H}_{2} \mathrm{O}-\mathrm{FeCl}_{2}-\mathrm{NaCl}$ systems. The temperature of ice melting (Tf) varies $-12^{\circ} \mathrm{C}$ and $-7^{\circ} \mathrm{C}$. These data, plotted with MacFlin program (Brown and Hagemann 1994), indicate salinities of almost $15 \%$ equivalent $\mathrm{NaCl}$.

Type II fluid inclusions show Te within the interval of $-55^{\circ} \mathrm{C}$ to $52^{\circ} \mathrm{C}$, possibly in the system $\mathrm{H}_{2} \mathrm{O}-\mathrm{CaCl}_{2}-\mathrm{NaCl}$. The measured halite dissolution temperatures $(\mathrm{Tm})^{2}$ are within the interval of $220^{\circ} \mathrm{C}$ to $270^{\circ} \mathrm{C}$. These data of $\mathrm{Tm}$ and $\mathrm{Tf}$, when plotted on the diagram of Bodnar and Vityk (1994) show high salinity, almost 35\% equivalent $\mathrm{NaCl}$.

In type I inclusions, the $\mathrm{Th}_{\text {total }}$ took place within the range $100^{\circ} \mathrm{C}$ to $180^{\circ} \mathrm{C}$, for pseudo-secondary, and $110^{\circ} \mathrm{C}$ to $330^{\circ} \mathrm{C}$ for primary inclusions, with an average value of $184.8^{\circ} \mathrm{C}$, to the liquid phase (Fig.7). These data support the idea of slow and gradual cooling of 


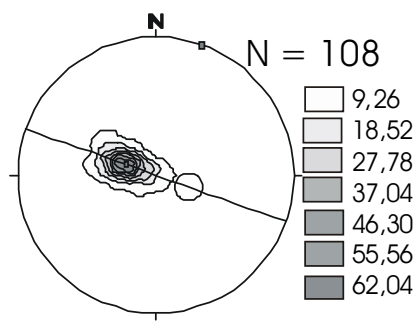

$\mathrm{Sn}+1$ planes from North section- Paiol Gold M inel.

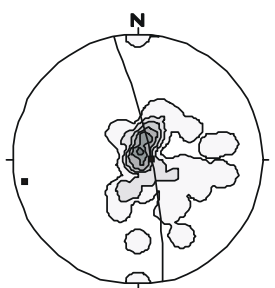

$N=73$

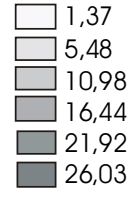

Isolines, planes and poles from fractures e faults of the North section- Paiol Gold Mine.

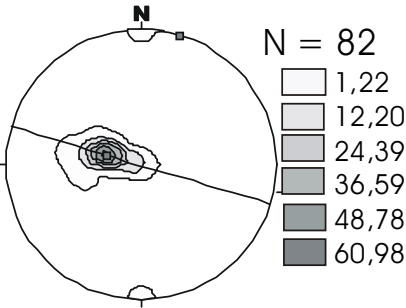

$\mathrm{S} n+1$ planes from Central section- Paiol Gold Mine.

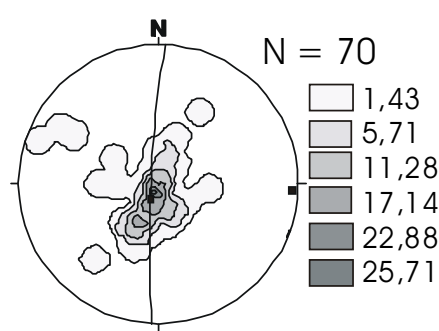

Isolines, planes and poles from fractures e faults of the Central section- Paiol Gold Mine.

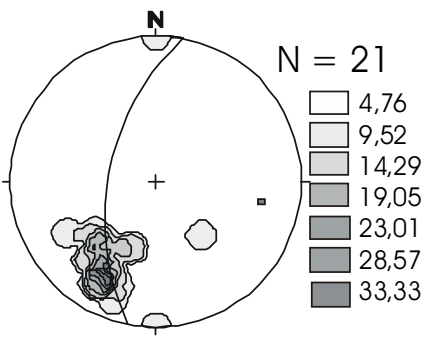

$\mathrm{Ln}+1$ planes from North section- Paiol Gold Minel.

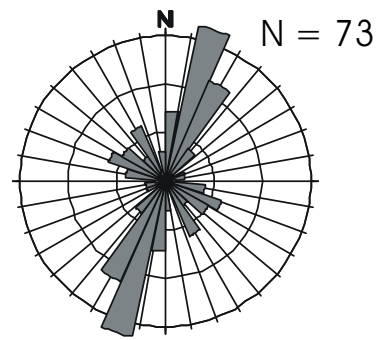

Fratures and faults from North section- Paiol Mine

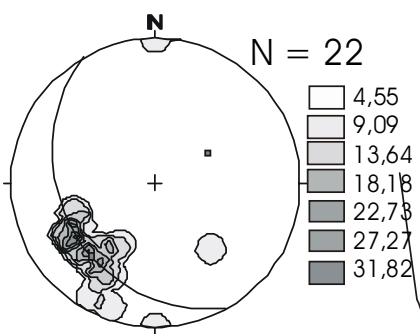

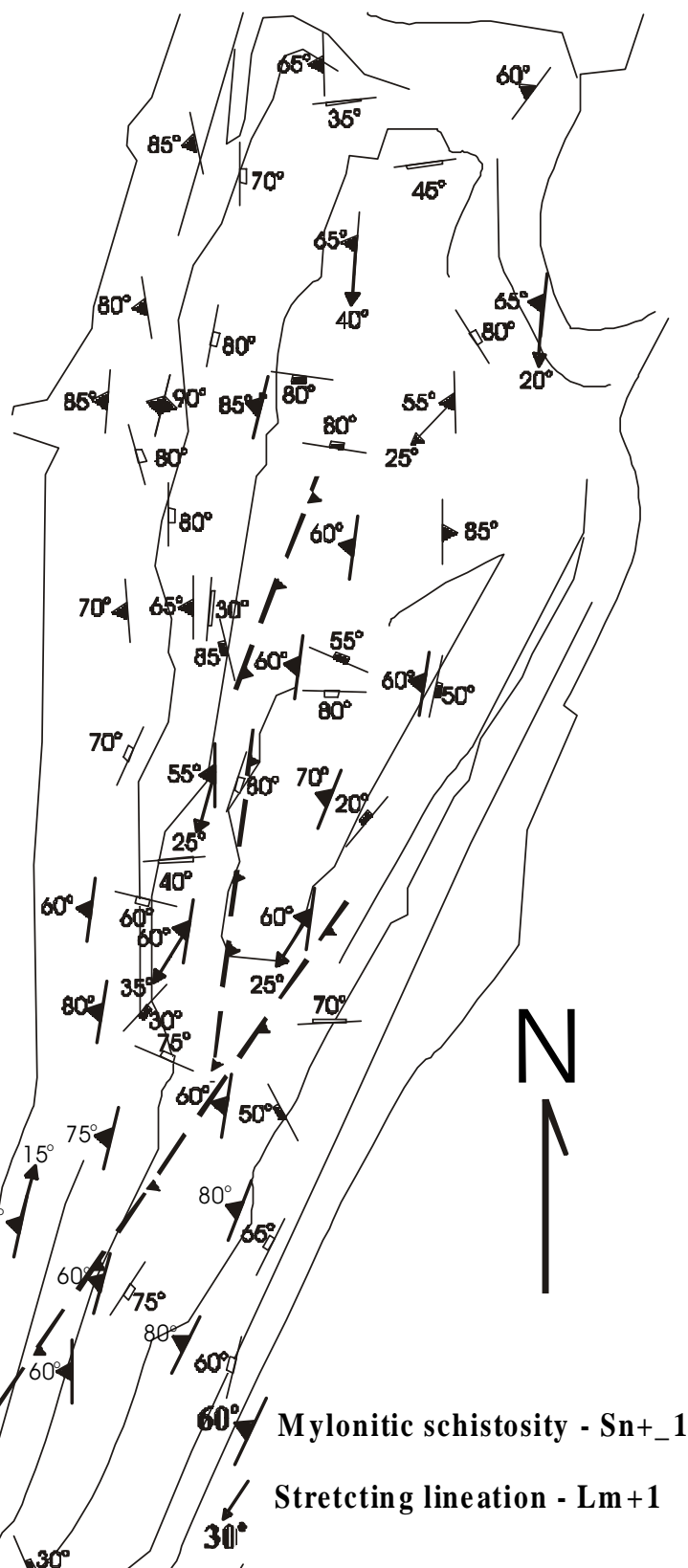

Fratures and faults from
Central section - Paipl Mine

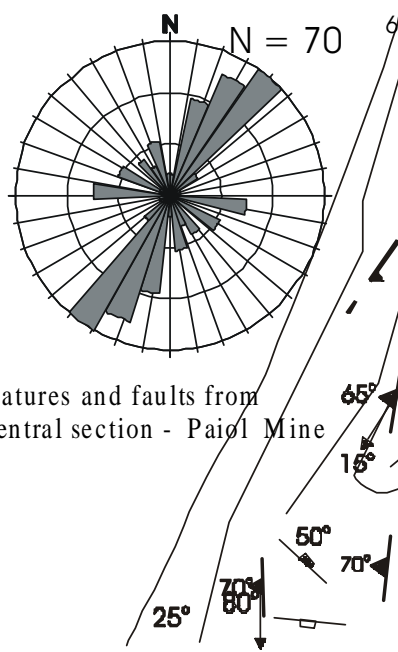

$40^{\circ}$ F2 Riedel - P

$\widetilde{20} \quad$ F3 Ried el - T

\section{M ain Faults}

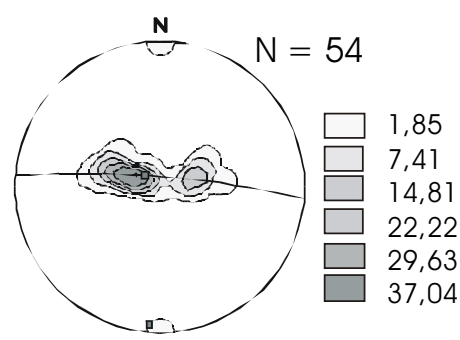

$\mathrm{Sn}+1$ planes from South section- Paiol Gold Minel.

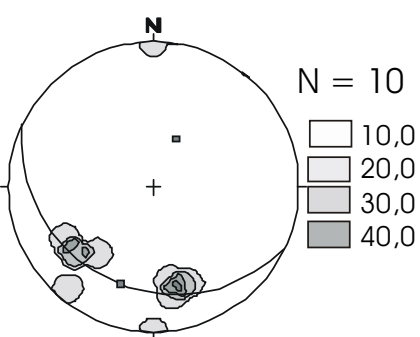

$\mathrm{Ln}+1$ planes from South section- Paiol Gold Mine.

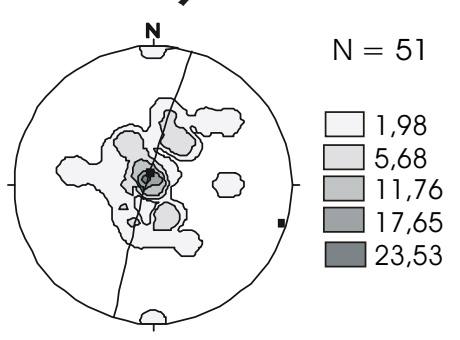

Isolines, planes and poles from fractures e faults of the South section-Paiol Gold Mine.

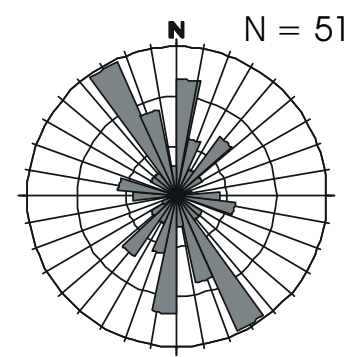

Fratures and faults from South section - Paiol Mine 


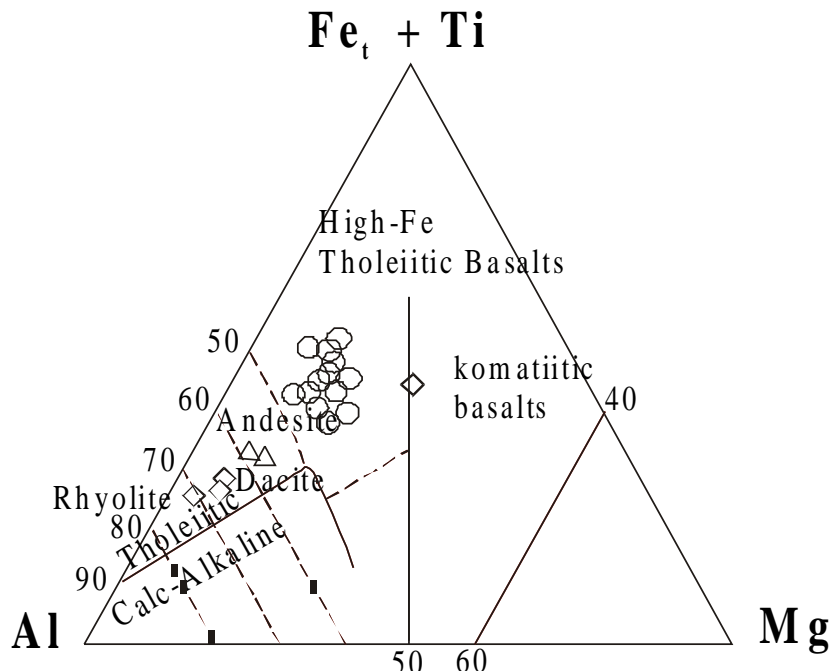

$\mathrm{FeO}$

Figure 3-Volcanic rocks from FD and FPA drill holes (symbols circles, diamonds and triangles, from volcanic rocks of drill cores FD, FPA hole), plotted on Jensen (1976) diagram.

\section{$\mathrm{FeO}$}

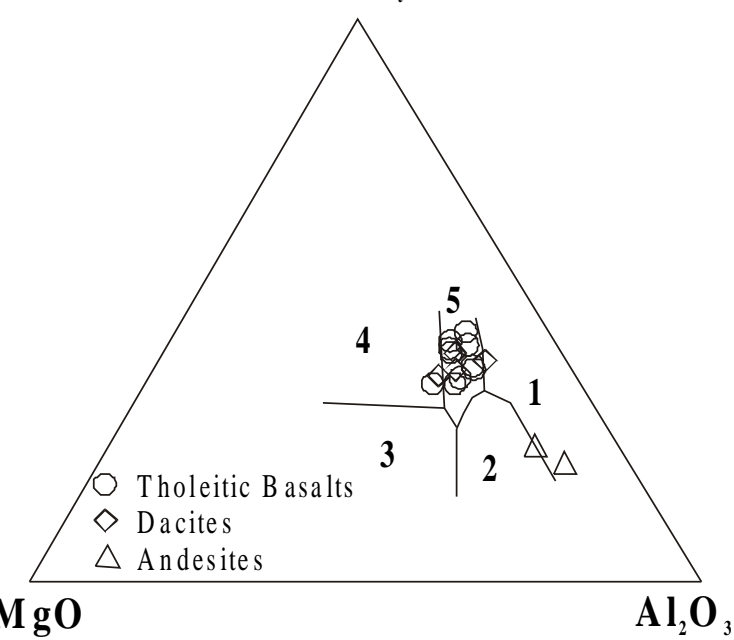

Figure 5-Volcanic rocks from Paiol Gold Mine (symbols as in Fig.3) plot in the within-plate basalt field of Pearce et al. (1977).

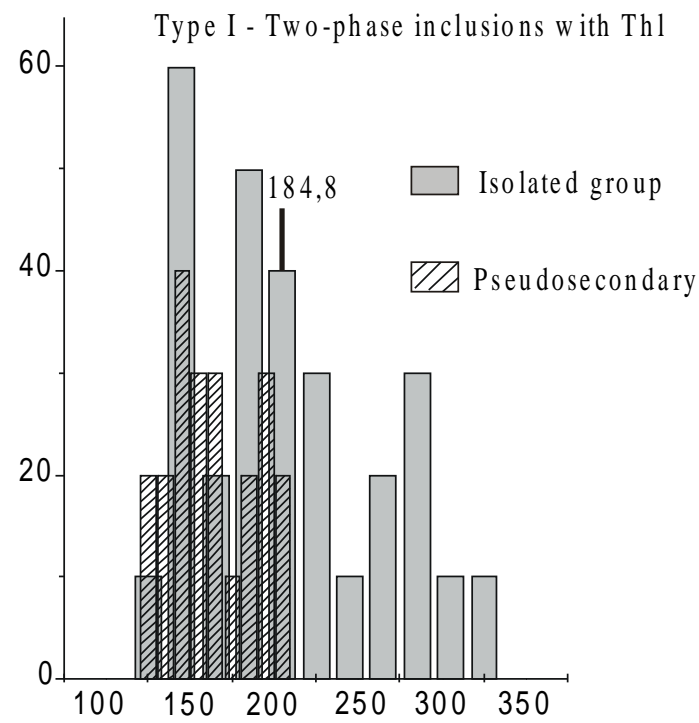

Figure 7-Histograms showing the homogenization temperatures (Thl) for liquid phase of isolated group and pseudosecondary inclusions of lode-type quartz from Paiol Gold Mine.

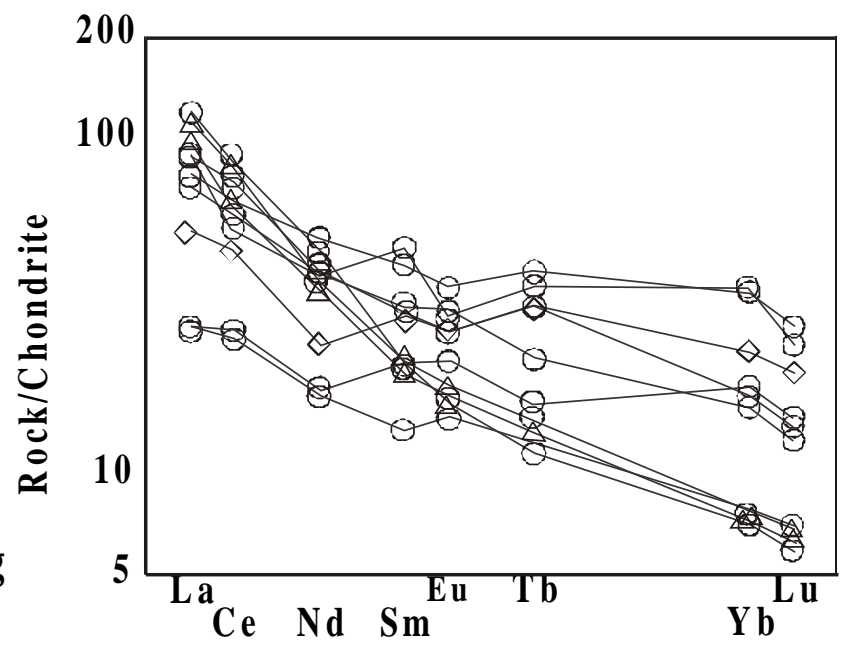

Figure 4-Chondrite normalized REE patterns for basaltic rocks from Paiol Gold Mine.

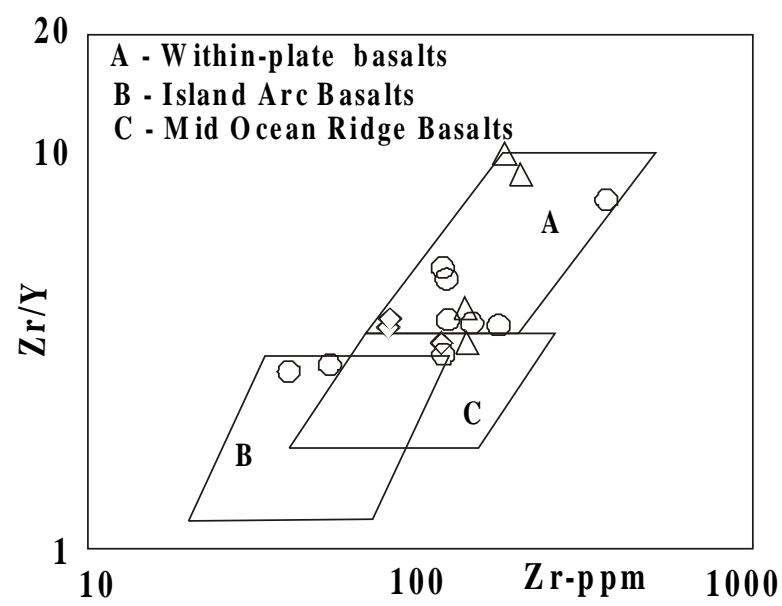

Figure 6-Volcanic rocks from Paiol Gold Mine (symbols as in Fig.3) showing continental basalt affinities field of Pearce et al. (1977)

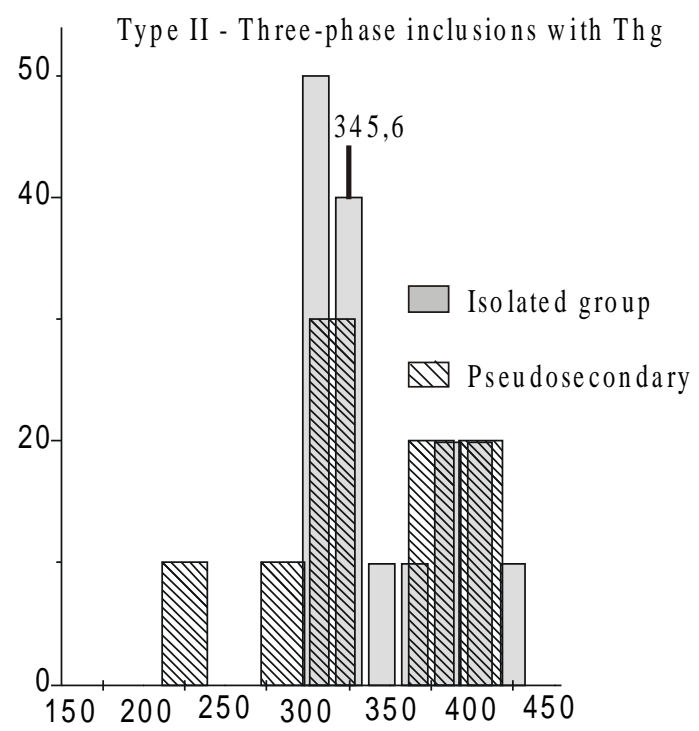

Figure 8-Histograms showing the homogenization temperatures ( $\mathrm{THg}$ ) for vapor phase of isolated group and pseudosecondary inclusions of lode-type quartz from Paiol Gold Mine. 
hydrothermal fluids. For type II, the $\mathrm{Th}_{\text {total }}$ shows values within the interval of $180^{\circ} \mathrm{C}$ to $370^{\circ} \mathrm{C}$, to pseudosecondary, and $270^{\circ} \mathrm{C}$ to $420^{\circ} \mathrm{C}$ to the vapor phase(Fig.8).

CONCLUSIONS The chemical data of Paiol gold mine show that the volcanic rocks have continental affinities, probably related to a continental rift environment. The gold mineralization can be related to the intersection of penetrative $\mathrm{S}_{\mathrm{n}+1}$ mylonitic foliation with extensional faults $\left(\mathrm{S}_{\mathrm{n}+2}\right)$ resulting in ore shoot zones. Fluid inclusion data indicate a process of boiling and aqueous-saline composition for the mineralizing fluids.

Acknowledgements: The authors are grateful to FAPESP (São Paulo Research Foundation), Process 96/06260-7 and 97/10885-5, for financial support for this research project. We thank CVRD (Cia. Vale do Rio Doce) for help during fieldwork and sampling at the mine site.

\section{References}

Bodnar R.J. \& Vityk M.O. 1994. MacFlinCor: A computer program for fluid inclusion data reduction and manipulation. In: B. de Vite \& M.L.Frezzetti (eds.), Fluid Inclusion s in Minerals: Methods and Applications. Short Course of the working group (IMA). Inclusions and Minerals, Pontignanc - Siena, Italy, 117-130.

Brown P.E. \& Hagemann S.G. 1994. MacFlinCor: A computer program for fluid inclusion data reduction and manipulation. In: B. de Vite \& M.L.Frezzetti (eds.), Fluid Inclusions in Minerals: Methods and Applications. Short Course of the working Inclusions in Minerals: Methods and Applications. Short Course of the wor
group (IMA). Inclusions and Minerals, Pontignanc-Siena, Italy, 231-250

Costa L.A.M., Portella A.C.P., Nilson A.A., Vale C.R.O., Marchetto C.L.M., Santos E.L., Meneguesso G., Inda H.A.V., Srena L.H., Marchetto M., Baptista M.B., Fratin O., Mosmann O., Oliveira T.F., Silva W.G. 1976. Projeto Leste Tocantins/Oeste do São Francisco. Relatório Final, Rio de Janeiro, DNPM/CPRM/PROSPEC, 200 p. (unpublished).

Costa J.B.S. 1984. Aspectos litoestruturais e evolução crustal da região centro-norte de Goiás.. Centro de Geociências da Universidade Federal do Pará. Ph. D. Thesis. 210p. Belém

Cruz, E.L.C.C. 1993. Geologia e Mineralizações auríferas de terreno granitóide greenstone de Almas-Dianópolis, Tocantins. Instituto de Geociências, Universidade de Brasília. M. Sc. Dissertation, 152p. Brasília.

Ferrari M.A.D. \& Choudhuri A. 1999a. Tectônica e a mineralização aurífera da Mina Córrego Paiol, Almas-TO. In: SBG, Simp. Nac. Estudos Tectônicos, 7, 34-36.

Ferrari M.A.D. \& Choudhuri A. 1999b. Variações químicas nas rochas vulcânicas do Greenstone Belt de Almas-TO. In: SBGq, Cong. Geoq. dos Países de Língua Portuguesa, 5, Cong. Bras. Geoq., 7, Anais, 492-494.
Jensen L.S.A. 1976. New cation plot for classifying subalkalic rocks. Ont. Div. Mines Misc. 66.

Padilha J.L. 1984. Prospecção de Ouro na região nordeste de Goiás. In: Projeto Pindorama -Docegeo. Rio Doce - Geologia e Mineração, 78-95.

Pearce T.H., Goraman B.E. Birkett T.C. 1977. The relationship between major element chemistry and tectonic enviroment of basic and intermediate volcanic rocks. Earth Planet Sci. Lett, 36:121-132.

Pearce T.H. \& Norry M. J. 1979. Petrogenetic implications of Ti, Zr, Y and Nb variations in volcanic rocks. Contrib. Mineral. Petrol., 69:33-47.

Roedder E. 1984. Fluid Inclusions. In: P.H. Ribbe (ed), Reviews in mineralogy: Mineral. Soc. Am., 12-644.

Rollinson H. 1999. Petrology and geochemistry of metamorphosed komatiites and basalts from the Sula Mountains greenstone belt, Sierra Leone. Contrib. Mineral. Petrol. 134: 86-101.

Silva A., Souza L.H., Ferreira M.C.B. 1990. Alteração hidrotermal da seqüência de rochas do alvo Córrego Paiol e mineralizacões auríferas associada.. In: SBG, Cong. Bras. Geol., 36, Natal, Anais, 3:1129-1143.
Contribution IGC-193

Received March 13, 2000 Accepted for publication May 15,2000 